\title{
EFEK DISINSENTIF PROGRAM RASKIN DAN PENGARUHNYA TERHADAP TRANSFER PANGAN ANTARGENERASI
}

\author{
Mohtar Rasyid \\ Fakultas Ekonomi Universitas Trunojoyo \\ Jalan Raya Telang PO.BOX 2 Kamal, Bangkalan. Telepon 031-3013483 \\ E-mail: mohtar_unijoyo@yahoo.co.id
}

Diterima 9 Desember 2011 / Disetujui 5 Mei 2012

\begin{abstract}
The objective of this research was to investigate disincentive and crowding-out effect food aid program (public transfer) in household level. Beside the humanitarian roles, there are widespread sceptisms of food assistance regarding its possible influence on disincentive to work and on crowding out of private transfer (inter-household or intergeneration transfer). Based on Indonesia Family Life Survey data and using instrumental variables approach, this paper estimates disincentive effect and crowding out effect "Rice Program for Poor Families" (Raskin) on intergenerational food transfer (child to parents transfer). This research observe significant negative impact on total household income. The decline in income mostly happened through a reduction in head household worker. The paper also find indication of crowding out relation between private and public transfers. It suggests that the Indonesian government should have designed its public transfer scheme carefully in order to improve the effectiveness and efficiency of its social safety net programs.
\end{abstract}

Keywords: food-aid program, dis-incentive effect, crowding-out effect, social safety net

\begin{abstract}
Abstrak: Tujuan penelitian ini adalah untuk menganalisis efek disinsentif dan efek mendesak program bantuan pangan dalam level rumah tangga. Tanpa mengabaikan pentingnya peran program pangan dalam misi kemanusiaan, tidak sedikit para ahli yang skeptis terhadap efektifitas program dengan alasan bahwa program semacam ini memiliki kemungkinan mengurangi insentif bekerja serta mengurangi bantuan pangan antar rumah tangga (transfer informal). Dengan menggunakan data survei Indonesia Family Life Survei dan pendekatan variabel instrumental, paper ini mengestimasi efek disinsentif untuk bekerja dan efek mendesak Program Beras untuk Keluarga Miskin (Raskin) terhadap transfer pangan antargenerasi (tepatnya, transfer dari anak terhadap orangtuanya). Hasil penelitian menunjukkan bahwa program memiliki efek negatif terhadap pendapatan keluarga. Penurunan pendapatan keluarga terjadi karena kepala keluarga mengurangi jam kerjanya. Penelitian juga menemukan indikasi adanya efek crowding-out transfer pemerintah terhadap transfer antargenerasi. Implikasi kebijakan yang disarankan adalah pentingnya pemerintah mendesain kebijakan transfer secara hati-hati dalam rangka memperbaiki efektivitas dan efisiensi program jaring pengaman sosial.
\end{abstract}

Kata kunci: program pangan, efek disinsentif, efek mendesak, jaring pengaman sosial

\section{PENDAHULUAN}

Program Beras untuk Keluarga Miskin atau yang lebih dikenal sebagai Raskin merupakan program nasional yang bertujuan untuk membantu Rumah Tangga Miskin (RTM) dalam memenuhi kebutuhan pangan. Program ini merupakan kelanjutan dari Program Operasi Pasar Khusus (OPK) yang awalnya didesain untuk mengurangi beban keuangan RTM akibat krisis ekonomi 1997. Sejak tahun 2002 OPK diubah menjadi Program Raskin karena sudah tidak lagi menjadi program darurat penanggulangan dampak krisis ekonomi sekaligus untuk 
mencerminkan sifat progam sebagai bagian dari social safety net programs bagi RTM (Mawardi dkk, 2008). Evaluasi Raskin selama ini lebih banyak menyorot masalah efektivitas pelaksanaan program seperti pencapaian indikator 6T: tepat sasaran, tepat jumlah, tepat harga, tepat waktu, tepat kualitas dan tepat administrasi. Sementara itu dampak kebijakan tersebut terhadap perubahan perilaku dan kesejahteraan penerima program belum dilakukan secara komprehensif.

Program Raskin sangat membantu masyarakat miskin dalam masa krisis ekonomi. Akan tetapi ketika program ini dilanjutkan pascakrisis ekonomi, maka harus dilakukan evaluasi secara menyeluruh dampak jangka panjang program terhadap perubahan perilaku masyarakat. Terlebih, terdapat indikasi bahwa program ini dalam taraf tertentu banyak mengalami apa yang kemudian dikenal sebagai targeting error. Berdasarkan kajian yang hati-hati, Barrett (2002) menjelaskan bahwa targeting error bisa jadi merupakan salah satu penyebab gagalnya program pemerintah dimaksud dalam memperbaiki ketersediaan tenaga kerja (labor supply) atau meningkatkan insentif masyarakat untuk bekerja.

Program bantuan pangan pada dasarnya dirancang utamanya untuk motif kemanusiaan. Barret dan Maxwell (2005) secara lebih spesifik menjelaskan bahwa program bantuan pangan peemrintah pada hakekatnya memiliki peran penting dalam kondisi darurat (emergency) serta tujuan pengembangan (developmental). Namun demikian, sebagaimana disitir oleh Sulaiman (2010), program semacam ini ini juga berpotensi memiliki dampak yang tidak diharapkan. Dampak sampingan yang mungkin muncul di antaranya adalah disincentive untuk bekerja dan crowding-out effect terhadap bantuan pangan yang sebelumnya diterima rumah tangga dari keluarganya (private transfer) maupun dari lembaga swadaya masyarakat. Sejumlah penelitian menunjukkan bahwa kecurigaan akan munculnya efek negatif ini bukanlah sesuatu yang mengada-ada. Sulaiman (2010) menemukan bukti bahwa program bantuan makanan justru menurunkan tingkat pendapatan keluarga di Sudan. Hasil yang kurang lebih sama juga dite- mukan di Sri Lanka oleh Sahn dan Alderman (1996) yang menyimpulkan bahwa subsidi pangan justru menurunkan semangat kerja (work effort) dan juga pendapatan dari bekerja.

Program bantuan pangan pemerintah juga terbukti memiliki efek mendesak atau mengurangi (crowding-out effect) alokasi bantuan pangan dari pihak lain baik dari perseorangan maupun dari lembaga non-pemerintah. Penelitian Lal dan Sharma (2009) membuktikan adanya efek ini dalam kasus bantuan pemerintah di daerah pedesaan India. Sementara di Nicaragua dan Honduras, Nielson dan Olinto (2007) juga menemukan bukti kuat bahwa pemberian bantuan tunai pemerintah terbukti mengurangi bantuan pangan antar anggota keluarga serta bantuan dari Lembaga Swadaya Masyarakat (LSM) setempat. Dalam taraf tertentu crowdingout effect justru berpotensi menimbulkan masalah bagi pemerintah itu sendiri mengingat tujuan program akan relatif sulit untuk dicapai.

Sejumlah kajian mengenai dampak program bantuan pangan telah banyak dilakukan. Dengan melakukan kajian review literatur, Lentz (2003) tidak dapat menemukan hubungan yang pasti berkaitan dengan efek disinsentif dari program, sementara efek crowding-out program pangan terhadap bantuan informal ditelaah oleh Dercon dan Krishnan (2003). Sambil mengajukan kritik metodologi terhadap kajian sebelumnya (Sahn dan Alderman, 1996), Abdulai et. al (2005) meneliti dampak program pangan terhadap penawaran tenaga kerja. Dengan menggunakan data cross-section Ethiopia dan melakukan kontrol terhadap karakteristik rumah tangga mereka menemukan bahwa tidak cukup bukti untuk menyatakan adanya efek disinsentif. Penelitian tersebut masih belum lepas dari isu endogenitas partisipasi program. Penelitian yang lebih komprehensif dilakukan oleh Gilligan dan Hoddinott (2007) untuk menguji dampak program terhadap produktivitas melalui perubahan status nutrisi, efeknya terhadap akumulasi aset dan pemutusan lingkaran kemiskinan. Dengan latar pendekatan randomize evaluation, Skoufias dkk (2008) menemukan bukti bahwa program baik berupa transfer uang maupun makanan tidak memiliki dampak terhadap partisipasi kerja di Mexico. Tadesse 
dan Shively (2009) melakukan kajian mengenai hubungan antara program dengan produksi lokal melalui efek harga. Sulaiman (2010) menguji dampak program bantuan pangan terhadap insentif kerja dan bantuan pangan dari dan ke pihak famili non-anggota rumah tangga di Sudan. Hasil penelitian menunjukkan bahwa program berimplikasi pada penurunan anak bekerja, namun sebagai konsekwensinya pendapatan total keluarga menjadi menurun. Penelitian ini didasarkan atas program yang di desain secara random. Program juga tidak menyebabkan adanya crowding-out effect. Peneliti berargumen bahwa relatif kecilnya jumlah transfer berakibat tidak ditemukannya efek ini. Jangka waktu evaluasi yang sangat pendek (satu tahun, 2008-2009) menyebabkan hasil kajian tidak bisa menangkap efek jangka panjang dari program.

Pengujian efek crowding-out secara umum juga telah banyak dilakukan. Kang dan Suwada (2003) dengan kajian terhadap perekonomian Korea Selatan, menemukan bukti bahwa efek crowding-out sangat signifikan. Hasil yang berbeda ditemukan oleh Kang (2004) dalam perekonomian Nepal. Meskipun menemukan motif transfer yang sama seperti di Korea Selatan, efek crowding-out tidak ditemukan secara signifikan. Peneliti berargumen bahwa besarnya transfer mempengaruhi perbedaan hasil antara dua kasus di atas. Penelitian Nielsen dan Olinto (2007) untuk Nicaragua dan Honduras menemukan bukti yang cukup signifikan dalam hal efek crowding-out program transfer pemerintah tidak hanya terhadap transfer uang dan makanan dari pihak keluarga namun juga terhadap bantuan dari lembaga non-pemerintah. Bukti adanya efek ini juga ditemukan oleh Lal dan Sharma (2009) di pedesaan India. Penelitian terbaru dari Gerardi dan Tsai (2010) di Taiwan juga menemukan efek crowding-out dari program transfer pemerintah. Hasil penelitian menunjukkan bahwa efek disinsentif dari program pemerintah lebih banyak dibuktikan di negaranegara berkembang sementara efek mendesak atau crowding-out ditemukan di berbagai kasus baik di negara berkembang maupun di negara maju sekalipun.

Efek transfer terhadap penawaran tenaga kerja telah banyak dibahas dalam teori (Blundell dan MaCurdy, 2000). Dalam model penawaran tenaga kerja statis sederhana, peningkatan pendapatan di luar kerja akan mempengaruhi keputusan bekerja dengan cara menggeser kurva anggaran keluar dari titik origin. Jika bantuan menambah penghasilan seseorang maka dia akan menjadi lebih makmur dan akan meningkatkan konsumsi barang sekaligus memperbanyak leisure. Akibatnya bantuan akan menyebabkan efek disinsentif untuk bekerja. Besarnya efek disinsentif ini tergantung dari beberapa faktor di antaranya asumsi model yang digunakan, peta preferensi individu serta besar dan struktur dari transfer.

Beberapa penelitian mengenai efek disinsentif dan crowding-out effect mulai banyak dilakukan di beberapa negara berkembang, sementara itu penelitian sejenis dengan kasus di Indonesia relatif masih terbatas. Kajian mengenai efektifitas pelaksanaan Program Raskin di Indonesia pernah dilakukan oleh SMERU (Mawardi dkk, 2008). Hasil kajian menunjukkan bahwa masalah distribusi dan ketepatan target merupakan salah satu aspek yang relatif sulit dipenuhi. Beberapa kendala yang terjadi di lapangan mengakibatkan terhambatnya penyaluran beras serta sasaran program (terutama sasaran harga) tidak dapat dipenuhi secara memuaskan. Secara umum, hasil kajian terhadap pelaksanaan Program Raskin menunjukkan bahwa efektivitas program masih relatif lemah. Hal ini ditandai oleh sosialisasi dan transparansi yang kurang memadai; target penerima, harga, jumlah, dan frekuensi penerimaan beras yang kurang tepat; biaya pengelolaan program yang tinggi; pelaksanaan pemantauan yang belum optimal; dan mekanisme pengaduan yang kurang berfungsi (Mawardi dkk, 2008). Kajian SMERU mengenai Program Raskin belum melihat dampak program terhadap perubahan perilaku penerima program khususnya yang terkait dengan perubahan dalam insentif bekerja maupun efek crowding-out dari program.

Berdasarkan beberapa kajian sebelumnya di berbagai negara dapat dikatakan bahwa isu evaluasi dampak program pangan lebih banyak menyoroti perubahan perilaku masyarakat setelah adanya program. Efektifitas program tidak 
hanya dievaluasi dalam jangka pendek melalui ketepatan sasaran program semata namun juga harus memperhatikan akibat yang mungkin kurang menguntungkan dari adanya program. Dengan demikian, evaluasi dampak program sudah seharusnya dilakukan secara lebih komprehensif. Mengingat masih relatif minimnya kajian mengenai evaluasi dampak program pangan di Indonesia maka paper ini melakukan kajian studi dampak evaluasi Program Raskin di Indonesia dengan tujuan khusus untuk menguji adanya dampak disinsentif dari program maupun dampak mendesak (crowding-out) yang mungkin terjadi.

\section{METODE PENELITIAN}

\section{Data IFLS}

Penelitian ini menggunakan data SAKERTI atau Indonesia Familly Life Survei (IFLS) dua gelombang (wave) terakhir yakni IFLS-3 dan IFLS4. Penggunaan data mikro dengan format longitudinal memungkinkan dilakukannya penelitian untuk memperoleh estimasi yang lebih konsisten. Terlebih IFLS menyediakan hasil survei rumah tangga Indonesia dengan jumlah kuesioner yang relatif kaya. Pada publikasi survei tahun 2007, IFLS menyediakan kuesioner untuk mengetahui informasi rumah tangga yang memperoleh bantuan Raskin (Seksi KSR, Buku 1). Dari 12.977 rumah tangga IFLS-4, dapat ditunjukkan bahwa sebanyak 5.662 rumah tangga menyatakan membeli raskin selama satu tahun terakhir, sementara 6.296 rumah tangga mengaku tidak membeli dan 1.013 rumah tangga menyatakan tidak tahu bahwa ada program raskin. Dari rumah tangga yang menerima raskin, diketahui bahwa sebagian besar rumah tangga (1.846 rumah tangga) membeli raskin sebanyak 12 kali dalam setahun sementara rata-rata pembelian Raskin selama periode yang sama adalah sebanyak 7 kali. Pagu pemerintah menetapkan bahwa rumah tangga miskin akan memperoleh alokasi $10 \mathrm{~kg}$ beras per bulan. Sementara sebagian besar rumah tangga IFLS (935 rumah tangga) membeli beras $5 \mathrm{~kg}$ selama satu bulan terakhir. Hanya $447 \mathrm{ru}-$ mah tangga yang bisa membeli beras Raskin hingga $10 \mathrm{~kg}$ selama satu bulan terakhir.

Hasil survei juga menunjukkan bahwa sebagian besar rumah tangga mengetahui jumlah maksimum beras Raskin yang bisa dibeli (5.584 rumah tangga), sementara 44 rumah tangga tidak mengetahui batas maksimum pembelian beras. Sebanyak 34 rumah tangga bahkan mengakui bahwa tidak ada batasan dalam alokasi Raskin. Hasil survei menunjukkan bahwa beras Raskin rata-rata dijual dengan harga Rp1.700 per $\mathrm{kg}$, sementara harga beras non-Raskin ratarata pada tahun yang sama adalah sebesar Rp4.200 per kg. Adapun kualitas beras Raskin menurut 237 rumah tangga adalah tinggi, sementara 2.927 rumah tangga menyatakan kualitas beras sedang dan 2.496 rumah tangga menyatakan kualitas beras Raskin adalah rendah. Berdasarkan hasil survei, rumah tangga IFLS penerima Raskin terbanyak adalah pada tahun 2007 dan 2008. Dari rumah tangga IFLS tersurvei, sebanyak 935 rumah tangga memutuskan untuk tidak membeli beras Raskin (meskipun berhak) dengan berbagai alasan.

Hasil survei menunjukkan bahwa alasan terbesar dari rumah tangga yang tidak mengambil jatah beras Raskin adalah tidak memiliki kupon. Sementara alasan tempat pengambilan yang terlalu jauh tidak menjadi alasan utama dari rumah tangga untuk tidak membeli beras Raskin. Hasil penelitian yang cukup mengejutkan adalah adalah bahwa terdapat beberapa responden yang tidak membeli beras Raskin karena tidak memiliki uang yang cukup. Dari hasil survei tersebut di atas maka dapat ditunjukkan bahwa masalah alokasi, distribusi, penetapan harga sekaligus mutu dari beras yang dijual merupakan faktor yang menyebabkan kurang optimalnya pelaksanaan Program Raskin. Catatan lain yang menarik adalah terdapat rumah tangga yang pada dasarnya berhak menerima Raskin namun tidak mengambil beras Raskin dengan alasan bahwa masih ada orang lain yang dipandang lebih membutuhkan.

\section{Strategi Estimasi}

Program Raskin tidak didesain secara randomize sehingga outcome antara kelompok penerima Raskin (treatment) dengan kelompok non-pene- 
rima (control) tidak bisa dibandingkan secara langsung dengan menggunakan teknik regresi biasa (OLS). Untuk mengatasi isu endogeneity karena tidak adanya counterfactual dengan karakteristik identik antara kelompok treatment dan kelompok kontrol, maka strategi estimasi yang biasa digunakan adalah menggunakan pendekatan duoble-difference atau difference in difference. Beberapa variabel penjelas yang digunakan adalah karakteristik rumah tangga yang terdiri atas usia kepala keluarga, jenis kelamin, tingkat pendidikan serta status pernikahan kepala rumah tangga.

Model dasar yang biasa digunakan dalam model bantuan pangan adalah sebagai berikut:

$y_{i t}=b_{0}+b_{1} T_{i t}+b_{2} F_{i t}+b_{3} T_{i t}{ }^{*} F_{i t}+b_{k} X_{i t}+u_{i t}$

Variabel treat $(T)$ menunjukkan apakah rumah tangga mendapat program atau tidak, sementara follow-up $(F)$ menunjukkan tahun observasi. Koefisien interaksi treat dengan follow-up tidak lain merupakan koefisien double difference yang menjadi interest utama dalam penelitian ini. Karakteristik rumah tangga, $X$, juga digunakan sebagai variabel kontrol. Beberapa isu penting terkait dengan estimasi adalah permasalahan endogenity yang berpotensi menghasilkan estimator yang bias. Untuk mengatasi masalah ini, biasa digunakan pendekatan fixed effect dengan asumsi bahwa perilaku un-observed variables yang berkorelasi dengan variabel program adalah konstan antar waktu.

Variabel outcome yang akan digunakan dalam penelitian ini adalah pendapatan rumah tangga dari bekerja, keikutsertaan anggota rumah tangga dalam aktivitas bekerja serta besarnya transfer pangan yang diberikan rumah tangga lain (private transfer). Tanda dan signifikansi dari koefisien $b_{3}$ akan menjadi indikator penting dari evaluasi. Tanda minus (dan signifikan) dari koefisien tersebut akan membuktikan hipotesis disincentive dan crowing-out dari adanya program Raskin. Dengan kata lain, program bantuan pangan tersebut secara umum justru mengakibatkan orang untuk lebih malas bekerja (disincentive) dan mengurangi jatah bantuan pangan dari rumah tangga lain (crowdingout).

Variabel outcome dalam penelitian ini terdi- ri atas pengeluaran konsumsi beras, pendapatan dari bekerja seluruh rumah tangga, status kerja kepala rumah tangga, jumlah anggota keluarga yang bekerja serta rata-rata waktu bekerja anggota keluarga setahun dalam minggu. Sementara itu untuk menguji efek crowding-out, penelitian ini fokus pada transfer pangan (dalam bentuk uang) dari anak (tepatnya, non-coresident children) kepada orang tuanya. Besarnya transfer dihitung berdasarkan selisih positif antara jumlah transfer pangan yang diterima dengan yang diberikan.

Pendekatan double difference dan intrumental variables (IV) merupakan alat yang umum digunakan dalam penelitian dampak program. Penggunaan pendekatan IV dilakukan dengan pertimbangan bahwa terdapat kemungkinan bahwa masalah endogeneity dapat timbul dari un-observed factor yang berubah antarwaktu. Oleh karena itu variabel treatment akan diinstrumentasi dengan variabel kepemilikan rumah. Untuk menjamin bahwa variabel ini eksogen, maka akan digunakan data kepemilikan rumah pada wave IFLS sebelumnya. Dengan demikian error term dalam estimasi model tidak akan berkorelasi dengan variabel kepemilikan rumah yang pre-determined.

Penggunaan double difference (DD) sebagai teknik estimasi memang relatif populer digunakan. Namun demikian, jika dalam periode awal program belum berjalan maka variabel interaksi program dengan waktu sekaligus koefisien yang diperlukan (yakni $b_{3}$ ) tidak akan diperoleh karena akan berkorelasi secara sempurna (multikolinearitas) dengan variabel program. Selain itu, pendekatan double difference digunakan untuk evaluasi dalam jangka waktu yang relatif pendek dengan asumsi bahwa variabel tak terobservasi diasumsikan tetap antarwaktu.

Program Raskin dilakukan sejak 2002 dan mulai efektif sejak tahun 2007-2008 sehingga tahun 2000 program masih belum berjalan. Untuk itu estimasi yang digunakan adalah menggunakan teknik first difference (FD) dengan kombinasi intrumental variable (IV).

$d y_{i t}=$ cons $+a_{1} d \underline{\text { raskin }}+a_{\mathrm{k}} d X_{i t}+s_{\mathrm{j}}+e_{\mathrm{ijt}}$

Model di atas merupakan persamaan first differ- 
ence dalam dua periode (tiap variabel dimulai dengan huruf $d$ ), dimana variabel program diinstrumentasi ( $\underline{\text { raskin }})$ oleh kepemilikan rumah periode sebelumnya. First stage dari model diatas adalah

draskin $=c_{0}+c_{1}$ house $_{\mathrm{it}-1}+c_{\mathrm{k}} d \mathrm{X}_{\mathrm{it}}+e_{\mathrm{it}}$

Variabel instrumen kepemilikan rumah (house) digunakan pada periode wave sebelumnya (predetermined).

Sebagaimana disinggung dalam hasil penelitian sebelumnya (Mawardi dkk, 2008), efektifitas pelaksanaan Program Raskin sangat ditentukan oleh kualitas penyebaran informasi atau sosialisasi yang dilakukan oleh aparat desa. Sosialisasi program pada level desa/kelurahan kerap menjadi titik lemah dalam evaluasi program. Heterogenitas level komunitas (desa) dalam model (2) ditangkap melalui koefisien $s_{\mathrm{j}}$ yang berbeda antarkomunitas namun konstan antarwaktu. Pendekatan fixed effect (FIXED) level desa (enumeration area) digunakan untuk mengoreksi endogeneity yang bersumber dari level desa. Dengan demikian penelitian ini menggunakan pendekatan first-difference yang dikombinasikan dengan pendekatan instrumental variables (IV) untuk mengantisipasi potensi endogeneity dari un-observed factor yang bisa mengakibatkan bias dalam estimasi koefisien program. Sementara itu untuk mengatasi bias akibat efek simultanitas, maka digunakan instrumen dari periode (wave) sebelumnya. Mengingat faktor distribusi beras dan sosialisasi program dalam level komunitas juga ditengarai ikut berkontribusi terhadap keberhasilan pelaksanaan Program Raskin, maka dalam penelitian ini juga dilakukan pendekatan fixed effect level komunitas setingkat desa/kelurahan (enumeration area). Survei IFLS menyertakan sebanyak 321 enumeration area (ea) yang tersebar diseluruh area survei di Indonesia.

\section{HASIL DAN PEMBAHASAN}

\section{Efek Disinsentif Program Raskin}

Estimasi pertama dilakukan untuk menguji dampak Program Raskin terhadap pengeluaran konsumsi rumah tangga untuk beras. Hasil estimasi dapat diperhatikan dalam Tabel 1. Terdapat dua kolom hasil perhitungan, kolom (1) menyajikan hasil estimasi model instrumental variable (IV) dan kolom (2) menyajikan hasil regresi dengan pendekatan fixed effect level desa atau enumeration area.

Tabel 1. Dampak Raskin terhadap Konsumsi (Dependent: Konsumsi Beras)

\begin{tabular}{lcc}
\hline VARIABLES & IV & FIXED \\
\hline draskin & $27,180^{* * *}$ & $110,420^{* * *}$ \\
dage & $(7,227.119)$ & $(41,091.903)$ \\
& $147^{* * *}$ & $215^{* * *}$ \\
dsex & $(21.796)$ & $(54.764)$ \\
& 1,614 & $6,830^{* *}$ \\
dmarried & $(1,020.420)$ & $(2,968.866)$ \\
& -259 & $-6,867^{*}$ \\
deduc & $(1,260.900)$ & $(3,991.396)$ \\
& $1,400^{* * *}$ & $3,380^{* * *}$ \\
constant & $(304.836)$ & $(1,224.253)$ \\
& $-17,029^{* * *}$ & $-73,849^{* *}$ \\
& $(6,133.566)$ & $(29,938.905)$ \\
Observations & 17,473 & 17,473 \\
\hline
\end{tabular}

Standard errors in parentheses

${ }^{* * *} \mathrm{p}<0.01,{ }^{* *} \mathrm{p}<0.05,{ }^{*} \mathrm{p}<0.1$

Secara umum penelitian menunjukkan bahwa program memiliki dampak positif terhadap peningkatan konsumsi beras rumah tangga. Hasil ini sesuai dengan harapan bahwa Program Raskin memang utamanya ditujukan untuk mengurangi beban finansial keluarga miskin dalam hal pemenuhan konsumsi bahan pangan. Tidak berlebihan jika banyak studi yang menyatakan bahwa Program Raskin cukup berhasil dalam menangani permasalahan kebutuhan masyarakat miskin akan bahan pangan (beras).

Hasil penelitian dampak Progran Raskin terhadap pengeluaran konsumsi beras serta faktor lain yang mempengaruhinya dapat diperhatikan dalam Tabel 1. Dalam Tabel 1, model fixed effect memberikan hasil estimasi yang signifikan untuk semua koefisien regresi yang diestimasi pada level signifikan konvensional. Usia kepala rumah tangga (age) berhubungan positif dengan konsumsi beras rumah tangga. Penjelasan 
yang masuk akal adalah peningkatan usia kepala rumah tangga sering diikuti dengan penambahan anggota rumah tangga sehingga pengeluaran konsumsi pangan seharusnya juga meningkat.

Konsumsi rumah tangga juga berhubungan positif dengan status kelamin rumah tangga. Rumah tangga dengan kepala rumah tangga laki-laki menunjukkan pengeluaran konsumsi beras yang lebih besar. Sementara itu pengeluaran konsumsi beras menjadi semakin menurun jika status kepala rumah tangga terikat pernikahan (married). Pendidikan kepala rumah tangga (educ) juga berasosiasi positif dengan pengeluaran konsumsi beras. Hasil penelitian menguatkan dugaan teori bahwa program bantuan pangan memang akan meningkatkan pengeluaran konsumsi pangan rumah tangga. Bantuan pangan dapat dianggap sebagai bentuk tambahan pendapatan tanpa bekerja. Dampak penambahan pendapatan tersebut terhadap insentif bekerja dari kepala keluarga dapat diperhatikan dalam Tabel 2 .

Tabel 2. Dampak Raskin terhadap Status Kerja (Dependent: Bekerja $=1$, Tidak=0)

\begin{tabular}{lll}
\hline \multicolumn{1}{c}{ VARIABLES } & \multicolumn{1}{c}{ IV } & FIXED \\
\hline draskin & $-0,34^{* * *}$ & $-0,97^{* * *}$ \\
& $(0,047)$ & $(0,166)$ \\
dage & $-0,0068^{* * *}$ & $-0,0073^{* * *}$ \\
dsex & $(0,000)$ & $(0,000)$ \\
& $0,17^{* * *}$ & $0,15^{* * *}$ \\
dmarried & $(0,011)$ & $(0,016)$ \\
& $0,047^{* * *}$ & $0,043^{* * *}$ \\
deduc & $(0,011)$ & $(0,015)$ \\
& 0,0016 & $-0,0018$ \\
dsize & $(0,001)$ & $(0,002)$ \\
& $0,008^{* * *}$ & $0,0094^{* * *}$ \\
constant & $(0,002)$ & $(0,002)$ \\
& $0,18^{* * *}$ & $0,49^{* * *}$ \\
Observations & $(0,024)$ & $(0,084)$ \\
\hline
\end{tabular}

Standard errors in parentheses

${ }^{* * *} \mathrm{p}<0.01,{ }^{* *} \mathrm{p}<0.05,{ }^{*} \mathrm{p}<0.1$

Hasil penelitian menunjukkan bahwa Program Raskin mengurangi probabilitas kepala rumah tangga untuk bekerja. Hasil ini konsisten dugaan bahwa peningkatan pendapatan nonbekerja bisa menurunkan insentif untuk bekerja. Hasil penelitian juga menghasilkan hubungan negatif antara usia kepala rumah tangga dengan status kerja. Semakin tua semakin kecil kemungkinan bahwa kepala rumah tangga akan tetap bekerja. Selanjutnya kepala rumah tangga laki-laki relatif lebih banyak bekerja dibandingkan dengan kepala rumah tangga perempuan.

Probabilitas bekerja dari kepala rumah tangga juga meningkat jika status kepala rumah tangga adalah sudah menikah. Pendidikan kepala rumah tangga terbukti tidak cukup signifikan korelasinya dengan probabilitas bekerja. Ukuran atau size keluarga juga berpengaruh positif terhadap aktivitas kepala rumah tangga untuk bekerja. Semakin banyak anggota keluarga yang ditanggung maka semakin besar kemungkinan kepala rumah tangga untuk bekerja.

Dampak Raskin terhadap status kerja kepala rumah tangga memiliki implikasi terhadap penurunan pendapatan total keluarga dari bekerja. Tabel 3 menunjukkan dampak Program Raskin terhadap total pendapatan keluarga penerima raskin.

\section{Tabel 3. Dampak Raskin terhadap Pendapatan (Dependent: Pendapatan Bekerja)}

\begin{tabular}{lcc}
\hline VARIABLES & IV & FIXED \\
\hline draskin & $-21,829,998^{* * *}$ & $-17,329,462^{*}$ \\
dage & $(3849642.823)$ & $(9971140.844)$ \\
dsex & $65,426^{* *}$ & $62,806^{* *}$ \\
& $(25,891.563)$ & $(27,026.510)$ \\
dmarried & $1,489,568$ & $1,771,332^{*}$ \\
& $(925,074.171)$ & $(938,403.735)$ \\
deduc & 176,376 & $-206,732$ \\
& $(900,555.319)$ & $(884,528.180)$ \\
dsize & 178,802 & $238,109^{*}$ \\
& $(111,610.954)$ & $(124,864.016)$ \\
constant & $1,874,135^{* * *}$ & $1,877,401^{* * *}$ \\
& $(145,311.057)$ & $(148,324.201)$ \\
& $\left(19,392,659^{* * *}\right.$ & $17,136,887^{* * *}$ \\
Observations & 17,476 & $(5037967.035)$ \\
\hline
\end{tabular}

Standard errors in parentheses

${ }^{* * *} \mathrm{p}<0.01,{ }^{* *} \mathrm{p}<0.05,{ }^{*} \mathrm{p}<0.1$ 
Pendapatan keluarga yang dimaksud dalam penelitian ini adalah pendapatan yang diperoleh dari bekerja. Sementara pendapatan keluarga di luar bekerja tidak dihitung. Dengan demikian maka interpretasi terhadap hasil penelitian ini harus dilakukan secara hati-hati dengan memperhatikan konteks variabel outcome yang dipilih.

Hasil perhitungan pada Tabel 3 dengan jelas menunjukkan bahwa Program Raskin memiliki dampak negatif terhadap pendapatan keluarga dari bekerja. Hasil ini konsisten baik dengan menggunakan pendekatan first difference dengan kombinasi IV (kolom 1), maupun pendekatan first difference dengan IV yang telah mengontrol heterogenitas efek komunitas atau fixed effect (kolom 2).

Relevansi pendekatan first difference untuk mengakomodasi adanya pengaruh faktor tak terobservasi (unobserved factor) dalam analisis pangan didukung oleh temuan Prasetyo, Marimin dan Samsudin (2010). Penelitian dimaksud menunjukkan bahwa kreatifitas lebih penting peranannya dalam memaksimumkan potensi masyarakat dibandingkan dengan fasilitas yang diberikan pemerintah. Kajian tersebut juga secara eksplisit menegaskan bahwa etos kerja dan kesadaran masyarakat merupakan faktor penentu yang lebih signifikan pengaruhnya dibandingkan dengan ketersediaan modal. Variabel kreatifitas, etos kerja dan kesadaran adalah variabel penting namun tidak mungkin terobservasi secara memuaskan dalam pendekatan kuantitatif. Dengan asumsi bahwa variabel ini konstan antarwaktu, maka pengaruhnya terhadap kinerja rumah tangga terobservasi dapat dilokalisir (dikontrol).

Pendekatan variabel instrumen (dalam hal ini adalah kepemilikan rumah periode sebelumnya) diperlukan untuk menghindari adanya bias akibat kemungkinan adanya efek timbal balik antara variabel terikat dengan variabel penentunya yang mempengaruhi signifikansi coefficient of interest. Kedua isu tersebut, yakni pengaruh dari variabel tak terukur dan kemungkinan adanya efek simultan, akan menyebabkan masalah endogenitas yang secara langsung berpengaruh terhadap kemungkinan adanya bias estimasi.
Perhitungan menunjukkan adanya perbedaan dalam besaran koefisien namun secara prinsip memiliki tanda yang umumnya sama untuk semua model. Usia berpengaruh positif terhadap pendapatan. Demikian pula kepala kelurga laki-laki secara statistik lebih banyak menghasilkan pendapatan dari bekerja dibandingkan dengan kepala keluarga perempuan. Status pernikahan kepala keluarga tidak mempengaruhi pendapatan. Semantara itu tingkat pendidikan terbukti memiliki pengaruh yang positif terhadap pendapatan dari bekerja. Ukuran keluarga juga memiliki dampak terhadap pendapatan dari bekerja. Semakin banyak anggota keluarga yang bekerja maka akan semakin tinggi total pendapatan keluarga dari bekerja.

\section{Efek Crowding-Out}

Salah satu sumber pendapatan non-bekerja keluarga bisa datang dari transfer pangan dari anggota keluarga yang tidak tinggal serumah. Transfer pangan antar rumah tangga (Transfer RT) ini terutama berasal dari anak terhadap orang tuanya. Bagaimana dampak program terhadap transfer pangan keluarga, dapat diperhatikan dalam Tabel 4.

Hasil perhitungan dengan menggunakan pendekatan IV menunjukkan bahwa Program Raskin memiliki pengaruh mendesak (crowdingout effect) terhadap transfer pangan anak terhadap orang tuanya. Dengan demikian efek positif berupa tambahan transfer bahan pangan dari pemerintah akan mengurangi alokasi transfer anak terhadap orang tuanya. Efek ini menjadi tidak signifikan jika digunakan pendekatan fixed effect dalam level enumeration area (setingkat desa atau kelurahan).

Hasil penelitian juga mencatat bahwa transfer pangan antargenerasi tersebut lebih banyak dipengaruhi oleh karakteristik anak (usia, jenis kelamin, status pernikahan dan tingkat pendidikan) serta frekwensi bertemu (contact) antara anak dengan orang tuanya). Di samping itu, itu hanya usia orang tua yang mempengaruhi transfer pangan, sementara karakteristik orang tua lainnya tidak memiliki dampak signifikan. Awalan p (sesudah d) dalam Tabel 4 mengacu pada karakteristik orang tua. Penelitian menunjukkan bahwa usia orang tua memiliki korelasi 
positif terhadap besarnya transfer pangan dari anak. Indikasi ini menunjukkan bahwa salah satu motif dari transfer antargenerasi adalah motivasi untuk menjamin kehidupan ekonomi orang tuanya (old-age security).

Tabel 4. Dampak Raskin Terhadap Transfer RT (Dependent: Transfer dari Anak)

\begin{tabular}{lcc}
\hline \multicolumn{1}{c}{ VARIABLES } & IV & FIXED \\
\hline draskin & $-60,568^{* *}$ & $-94,694$ \\
dage & $(25,464.353)$ & $(69,772.004)$ \\
dmale & $-636^{* * *}$ & $-677^{* * *}$ \\
& $(139.268)$ & $(175.051)$ \\
dmarried & $4,601^{* *}$ & $10,358^{* * *}$ \\
& $(2,051.368)$ & $(2,265.876)$ \\
deduc & $17,984^{* * *}$ & $25,555^{* * *}$ \\
& $(3,279.331)$ & $(3,452.071)$ \\
dworking & $1,052^{* * *}$ & $1,364^{* * *}$ \\
& $(355.411)$ & $(398.721)$ \\
dcontact & $-3,200$ & $-5,058$ \\
dmember & $(2,532.415)$ & $(3,753.426)$ \\
& $1,962^{* * *}$ & $2,554^{* * *}$ \\
dp_age & $(687.093)$ & $(764.273)$ \\
& 7,648 & 7,709 \\
dp_male & $(9,575.124)$ & $(11,421.103)$ \\
& $155^{* *}$ & $138^{* *}$ \\
dp_married & $(64.308)$ & $(69.186)$ \\
& -207 & -928 \\
constant & $(2,254.196)$ & $(2,500.150)$ \\
& 952 & -472 \\
Observations & $(2,926.209)$ & $(3,308.195)$ \\
\hline & $33,027^{* *}$ & 52,615 \\
& $(14,555.814)$ & $(39,785.402)$ \\
& 11,502 & 11,502 \\
\hline & &
\end{tabular}

Standard errors in parentheses

${ }^{* * *} \mathrm{p}<0.01,{ }^{* *} \mathrm{p}<0.05,{ }^{*} \mathrm{p}<0.1$

Transfer pangan dari anak juga terindikasi oleh motif balas jasa atas investasi pendidikan yang dilakukan oleh orang tua terhadap anaknya saat belia. Motif ini bisa ditelusuri dari signifikansi lamanya pendidikan anak terhadap besarnya transfer. Anak dengan tingkat pendidikan yang lebih tinggi cenderung memberikan transfer yang lebih besar. Investigasi terhadap motif dari transfer antargenerasi ini sangat penting untuk dikaji terkait dengan analisis kebijakan publik. Jika motif dari transfer lebih banyak bersifat altruism, maka kebijakan peme- rintah berupa transfer publik (termasuk transfer pangan) akan mendesak secara penuh transfer non-publik yang terjadi dalam masyarakat (termasuk transfer antargenerasi). Jika motivasi transfer muncul oleh karena motif lain (seperti balas jasa dan pengasuhan orang tua) maka transfer antar generasi tidak akan terpengaruh oleh transfer dari pemerintah.

Motif pertukaran (exchange) dari transfer juga dapat terindikasi dari signifikansi variabel intensitas pertemuan (contact). Besarnya intensitas pertemuan antara anak dengan orangtuanya memiliki hubungan positif dengan jumlahnya transfer. Intensitas kontak dalam penelitian mengenai transfer intergenerasi merupakan indikasi terhadap adanya impure altruism (Laferrere, 2006). Anak memberikan bantuan finansial sementara orang tua memberikan layanan seperti membantu pekerjaan rumah tangga maupun mengurus cucu sebagaimana lazim terjadi dalam tipe keluarga di beberapa negara berkembang (extended family).

Hasil penelitian menunjukkan bahwa Program Raskin terbukti memiliki dampak positif terhadap peningkatan pengeluaran konsumsi beras. Sementara terjadi peningkatan konsumsi beras, program juga mengurangi alokasi kepala keluarga untuk bekerja. Sebagai akibatnya, pendapatan total rumah tangga dari bekerja mengalami penurunan. Dengan kata lain, efek disinsentif dari bekerja sebagai akibat program hanya berimbas pada kepala rumah tangga.

Temuan lain menunjukkan bahwa program juga terbukti mengurangi transfer pangan dari anak terhadap orang tua. Hasil ini menunjukkan indikasi adanya efek crowding-out dari program terhadap transfer bahan makanan lintas generasi. Bantuan Program Raskin, bagaimanapun juga dapat dipandang sebagai tambahan pendapatan rumah tangga tanpa perlu bekerja, namun tambahan pendapatan ini bisa terkikis oleh perubahan perilaku penerima program yang mengurangi alokasi bekerja maupun oleh berkurangnya alokasi transfer pangan yang biasanya diterima oleh anggota keluarga yang tidak tinggal serumah (biasanya dari anak terhadap orang tua yang hidup terpisah). Hasil ini sebenarnya mengkonfirmasi sebagian dari beberapa hasil penelitian sejenis yang dilaku- 
kan di banyak negara berkembang.

Penelitian menunjukkan bahwa meskipun indikasi efek crowding-out Program Raskin terbukti signifikan akan tetapi besarannya relatif kecil. Bukti statistik juga menunjukkan bahwa efek ini menjadi tidak signifikan jika dilakukan kontrol terhadap heterogenitas dalam wilayah (fixed effect). Ini berarti bahwa efek mendesak dari Program Raskin tidak bersifat umum namun hanya terjadi dalam beberapa kasus wilayah tertentu. Hasil ini konsisten dengan penelitian Purwaningsih dkk (2010) mengenai pola pengeluaran pangan yang menyimpulkan bahwa rumah tangga di wilayah perkotaan memiliki porsi pengeluaran beras yang lebih kecil dibandingkan dengan rumah tangga di wilayah pedesaan. Heterogenitas pola pengeluaran pangan antar wilayah ini dapat menjadi penjelas terhadap melemahnya efek crowdingout effect dari Program Raskin. Masyarakat kota yang relatif individualis tentunya memiliki karakter yang berbeda dengan masyarakat pedesaan yang memiliki ikatan kekeluargaan cukup kuat.

\section{Transfer Antargenerasi}

Kajian mengenai efek disinsentif dan efek crowding-out sangat terkait dengan analisis transfer antargenerasi yang saat ini mulai marak dilakukan di Indonesia. Penelitian Schueler (2007) menunjukkan bahwa transfer antarrumah tangga menyebabkan efek disinsentif bekerja terhadap anggota keluarga penerima. Efek ini tidak signifikan pada pengurangan waktu bekerja anak. Dengan demikian tidak ada perbaikan dalam nasib pekerja anak dengan adanya transfer. Hasil ini berbeda dengan kajian Sulaiman (2010) di Sudan yang menyimpulkan bahwa ditemukan bukti signifikan adanya efek pengurangan jam kerja anak dari adanya transfer yang berimbas pada pengurangan total pendapatan keluarga.

Hasil penelitian dalam paper ini hingga taraf tertentu mendukung temuan Schueler (2007) mengenai efek disinsentif bekerja dari adanya transfer. Perbedaan utamanya terletak pada sumber transfer, dalam Schueler (2007) sumber transfer adalah private sedangkan dalam pene- litian ini sumber transfer adalah pemerintah. Namun demikian, inti dari temuan ini menunjukkan bahwa tambahan pendapatan non-bekerja menyebabkan penurunan dalam alokasi waktu untuk bekerja. Akibatnya, pendapatan keluarga dari bekerja menjadi menurun. Berbeda dengan Schueler (2007), dalam kasus Raskin pengurangan alokasi bekerja hanya terjadi pada kepala keluarga, sementara anggota keluarga lain tidak terpengaruh.

\begin{tabular}{lcc}
$\begin{array}{l}\text { Tabel 5. Dampak Raskin terhadap Waktu Kerja } \\
\text { (Dependent: Hari Kerja Anggota } \\
\text { Keluarga) }\end{array}$ & \\
\hline VARIABLES & IV & FIXED \\
\hline draskin &, 59 & 5,6 \\
dage & $(1,659)$ & $(4,550)$ \\
&,- 002 &,- 0048 \\
dsex & $(0,012)$ & $(0,013)$ \\
dmarried &, 17 &, 41 \\
& $(0,451)$ & $(0,479)$ \\
deduc &,- 033 &, 011 \\
& $(0,433)$ & $(0,441)$ \\
dsize &, 079 &, 059 \\
& $(0,052)$ & $(0,056)$ \\
Constant &, 024 &,- 0064 \\
& $(0,067)$ & $(0,072)$ \\
&,- 12 & $-2,6$ \\
Observations & $(0,859)$ & $(2,311)$ \\
\hline
\end{tabular}

Standard errors in parentheses

${ }^{* * *} \mathrm{p}<0.01,{ }^{* *} \mathrm{p}<0.05,{ }^{*} \mathrm{p}<0.1$

Tabel 5 menunjukkan bahwa Program Raskin tidak memiliki pengaruh yang signifikan terhadap alokasi bekerja anggota rumah tangga. Variabel kontrol lainnya juga tidak menghasilkan estimasi koefisien yang signifikan dalam level konvensional. Untuk membuat perbandingan yang setara dengan hasil pada Tabel 1, variabel status kerja anggota keluarga (selain kepala keluarga) digunakan sebagai variabel dependent. Hasil perhitungan juga menunjukkan bahwa Program Raskin tidak memiliki efek signifikan terhadap status kerja anggota keluarga. Estimasi model dimaksud dapat diperhatikan dalam Tabel 6. 
Tabel 6. Efek Raskin pada Status Kerja Keluarga (Dependent: Status Kerja Anggota Keluarga)

\begin{tabular}{lcc}
\hline VARIABLES & \multicolumn{1}{c}{ IV } & FIXED \\
\hline draskin & 0,11 & 0,3 \\
& $(0,117)$ & $(0,313)$ \\
dage & $-0,000065$ & 0,000087 \\
& $(0,001)$ & $(0,001)$ \\
dsex & 0,019 & 0,029 \\
& $(0,028)$ & $(0,029)$ \\
dmarried & 0,026 & 0,02 \\
& $(0,027)$ & $(0,028)$ \\
deduc & 0,003 & 0,0051 \\
& $(0,003)$ & $(0,004)$ \\
dsize & $-0,015^{* * *}$ & $-0,016^{* * *}$ \\
& $(0,004)$ & $(0,005)$ \\
Constant & $-0,066$ & $-0,16$ \\
& $(0,060)$ & $(0,158)$ \\
Observations & 17,476 & 17,476 \\
\hline
\end{tabular}

Standard errors in parentheses

*** $p<0.01,{ }^{* *} p<0.05, * p<0.1$

Hasil estimasi dalam Tabel 6 semakin memperjelas temuan dalam penelitian ini. Efek disinsentif bekerja dari Program Raskin hanya berlaku pada kepala keluarga sementara anggota keluarga yang lain tidak terpengaruh oleh adanya program. Efek disinsentif dari program mungkin tidak selamanya negatif jika kepala keluarga termasuk dalam kategori usia senja (old age). Efek disinsentif bekerja juga menguntungkan jika justru mengurangi jumlah pekerja anak usia sekolah. Untuk mengupas lebih jauh mengenai efek program lintas generasi, terlebih dahulu akan dilakukan review atas penelitian sebelumnya mengenai transfer antargenerasi di Indonesia.

Penelitian awal mengenai transfer antargenerasi di Indonesia dilakukan oleh Raut dan Tran (2005). Meskipun tidak secara spesifik menganalisis dampak program tertentu, namun implikasi penelitian dimaksud cukup penting untuk dicatat. Berdasarkan perhitungan dari derivatif transfer, Raut dan Tran (2005) menemukan indikasi bahwa terdapat potensi crowding-out penuh dalam studi transfer antargenerasi. Sebagai ilustrasi, jika pemerintah memberikan transfer sebesar Rp200 ribu, maka penerima transfer akan kehilangan transfer sejumlah uang yang sama dari anggota keluarga yang lain. Kesimpulan ini tentunya berbeda dengan hasil temuan dalam paper ini yang tidak menemukan adanya efek crowding-out secara penuh. Efek mendesak ini justru menghilang jika dilakukan kontrol terhadap heterogenitas area.

Perbedaan hasil temuan ini dapat ditelusuri dari berbagai aspek. Pertama, Raut dan Tran (2005) tidak menguji secara langsung dampak program tertentu terhadap transfer antargenerasi. Sementara analisis dalam paper ini menggunakan Program Raskin sebagai variable of interest dari penelitian. Kedua, data yang digunakan oleh Raut dan Tran (2005) adalah data cross-section IFLS gelombang pertama (IFLS-1) sehingga potensi bias dari faktor tak terukur tidak bisa dikoreksi. Ketiga, berbeda dengan asumsi model yang digunakan alam penelitian ini, model Raut dan Tran (2005) lebih berorientasi pada model altruisme sementara model dasar yang digunakan dalam penelitian ini lebih fleksibel. Beberapa perbedaan pendekatan ini sedikit banyak akan berperan dalam menjelaskan perbedaan hasil termuan. Diskusi mengenai hasil penelitian tentang transfer antargenerasi akan lebih tajam jika dilakukan ulasan juga terhadap hasil-hasil kajian yang telah dilakukan dalam ranah kajian yang sama.

Penelitian terkait dengan transfer antargenerasi di negara maju lebih banyak menemukan pola downward-flow transfer (transfer dari orang tua ke anak). Penelitian Cox (1990) serta Cox dan Rank (1992) sebagai suatu misal, meneliti motif transfer kekayaan orang tua ke anak; lebih bersifat altruistik atau hanya sedekar motif pertukaran. Penelitian ini menunjukkan bahwa adanya hambatan likuiditas anak merupakan salah satu faktor penting yang menyebabkan orang tua harus berbagi dengan anaknya. Dengan setting sosial-budaya yang berbeda, model downward-flow tidak bisa diterapkan untuk negara berkembang karena pola transfer di negara berkembang lebih banyak bersifat sebaliknya; upward-flow atau dari anak ke orang tua.

Kajian Cameron dan Clark (2001) di Indonesia menemukan bahwa transfer pendapatan dari anak kepada orang tuanya tidak terpengaruh oleh kondisi orang tua maupun kemampuan anak. Berdasarkan pengamatan mereka, 
tingkat pendidikan anak sama sekali tidak berpengaruh terhadap besarnya transfer. Transfer dari anak tidak serta merta mengurangi jam kerja orang tua berusia lanjut. Dalam hal ini kedua peneliti tersebut menggunakan data Indonesia Family Life Survei (IFLS) gelombang pertama (1993). Apabila dikaitkan dengan penelitian dalam paper ini maka akan ditemukan hubungan yang menarik. Hasil penelitian menunjukkan bahwa alokasi bekerja orang tua tidak terpengaruh oleh adanya transfer dari anak namun akan berkurang oleh adanya transfer pemerintah.

Studi Frankenberg dkk (2002) menemukan bukti bahwa berbagai motif transfer cocok dengan kasus transfer intergenerasi di Indonesia mulai dari motif altruistik, pertukaran (exchange) hingga motif balas jasa (repayment of implisit loan). Penelitian ini membuktikan bahwa pendidikan anak berpengaruh positif terhadap transfer. Selanjutnya Park (2003), juga dengan menggunakan data IFLS-1 (1993) menemukan motif balas jasa (repayment implisit loan) anak kepada orang tuanya. Akan tetapi, pendidikan anak dalam pengujian lebih lanjut tidak berpengaruh secara sistematis terhadap besarnya transfer. Semakin tinggi tingkat pendidikan tidak serta merta menyebabkan jumlah transfer yang lebih banyak. Untuk menguji motif repayment loan ini, Park (2003) memperbaiki metode yang digunakan oleh Lillard dan Willis (1997) serta Frankenberg dkk (2002) dengan mengontrol pengaruh variabel pendapatan responden untuk melihat dampak pendidikan terhadap besarnya transfer. Beberapa kajian di Indonesia ini dengan jelas menunjukkan bahwa motif altruistik bukanlah motif yang mendominasi adanya transfer sehingga kemungkinan adanya desakan penuh dari kebijakan pemerintah tidak dapat diterima. Dengan demikian maka relatif terbatasnya efek crowding-out dalam penelitian ini didukung oleh beberapa penelitian sebelumnya.

Kajian mengenai transfer antargenerasi lebih banyak difokuskan pada motivasi dari transfer serta faktor penentu dari transfer. Sementara transfer semacam ini sebenarnya juga memiliki implikasi yang cukup penting terhadap kesejahteraan rumah tangga. Studi yang mengkaji dampak transfer terhadap kesejahteraan lebih banyak mengupas pengaruh kiriman uang dari tenaga kerja migran (remittance) terhadap kesejahteraan anggota keluarga yang ditinggalkannya. Hasil penelitian di Ghana menunjukan bahwa transfer uang dari tenaga kerja migran berpengaruh positif terhadap kesejahteraan rumah tangga dan meminimalisir dampak kejutan ekonomi meski sebatas pada rumah tangga petani jagung (Quartey, 2006).

Penelitian mengenai dampak transfer uang juga dilakukan di beberapa negara Asia. Dengan menggunakan data makro panel Asia Pasifik tahun 1993-2003, Jongwanich (2007) menemukan bukti bahwa kiriman uang dari tenaga kerja migran memiliki efek positif terhadap penurunan kemiskinan melalui peningkatan pendapatan, mempertahankan tingkat konsumsi (consumption smoothing) dan kemudahan akses terhadap modal. Namun demikian efek transfer ini terhadap pertumbuhan yang diindikasikan melalui investasi domestik dan pengembangan sumber daya manusia relatif tidak cukup signifikan.

Analisis pengaruh transfer uang dari tenaga kerja migran dengan menggunakan data mikro mulai banyak dilakukan di samping data agregat (data makro). Dalam kasus Bangladesh, Raihan dkk (2009) menguji efek transfer uang terhadap kesejahteraan rumah tangga dan pengurangan kemiskinan. Hasil penelitian menunjukkan bahwa kiriman uang dari luar negeri memiliki dampak positif terhadap pengeluaran bahan makanan dan perumahan. Rumah tangga yang menerima kiriman uang juga memiliki probabilitas yang rendah sebagai rumah tangga miskin. Dengan menggunakan pendekatan yang hampir sama, Ahmed dkk (2010) meneliti dampak kiriman uang dari tenaga kerja migran terhadap kesejahteraan rumah tangga di Pakistan. Hasil penelitian juga menunjukkan bahwa rumah tangga yang menerima transfer uang juga memiliki probabilita yang kecil untuk teridentifikasi sebagai rumah tangga miskin.

Pengaruh dari kiriman uang terhadap indikator kesejahteraan rumah tangga juga dilakukan di Indonesia dengan menggunakan data IFLS-3 dan IFLS-4. Nguyen dan Purnamasari 
(2011) melaporkan bahwa pengaruh kiriman uang dari tenaga kerja migran terhadap kesejahteraan keluarga yang ditinggalkannya berbeda untuk kasus tenaga kerja pria dan wanita. Untuk kasus tenaga kerja pria, kiriman uang memiliki efek disinsentif terhadap penawaran tenaga kerja rumah tangga. Sementara dalam kasus tenaga kerja wanita, transfer uang mengakibatkan pengurangan tenaga kerja anak. Tidak terdapat bukti signifikan yang menunjukkan keterkaitan antara transfer dari tenaga migran terhadap jumlah anak yang bersekolah. Penelitian ini tidak menggunakan data besarnya transfer sebagai variabel penjelas, namun menggunakan informasi bahwa salah satu anggota keluarga ada yang melakukan migrasi ke luar negeri pada survei terakhir.

\section{Implikasi Penelitian}

Penelitian mengenai dampak transfer terhadap indikator kesejahteraan rumah tangga membawa implikasi penelitian yang cukup penting. Pertama, transfer publik maupun privat merupakan elemen penting dalam menganalisis kesejahteraan keluarga. Kedua, efek dari transfer tidak selamanya positif namun juga berpotensi memiliki dampak negatif seperti penurunan insentif bekerja serta berkurangnya alokasi transfer dari sumber lain.

Hasil penelitian menunjukkan bahwa Program Raskin berhasil mengurangi beban finansial keluarga miskin dengan meningkatnya pengeluaran konsumsi pangan (beras). Di samping itu program ini memiliki dampak sampingan yang kurang menguntungkan khususnya bagi keluarga miskin. Sebagaimana juga yang terjadi di Sudan, program pangan ini justru menurunkan total pendapatan keluarga dari bekerja. Hasil kajian di Sudan menunjukkan bahwa penurunan pendapatan terjadi karena penurunan jam kerja anak, sementara dalam penelitian ini mengindikasikan bahwa penurunan pendapatan dari bekerja terjadi karena berkurangnya kepala keluarga yang bekerja.

Dampak Program Raskin terhadap penurunan jumlah anak usia sekolah tidak signifikan. Estimasi model untuk mengetahui dampak program terhadap status kerja anak usia sekolah dapat diperhatikan dalam Tabel 7.
Tabel 7. Efek Raskin pada Status Kerja Anak (Dependent: Jumlah Anak Bekerja)

\begin{tabular}{lcc}
\hline VARIABLES & IV & FIXED \\
\hline draskin &, 0074 &, 031 \\
& $(0,015)$ & $(0,039)$ \\
dage &,- 00015 &,- 000087 \\
& $(0,000)$ & $(0,000)$ \\
dsex &,$- 0077^{* *}$ &,$- 0082^{* *}$ \\
& $(0,004)$ & $(0,004)$ \\
dmarried &, 0044 &, $0058^{*}$ \\
& $(0,003)$ & $(0,003)$ \\
deduc &,- 00026 &, 000048 \\
& $(0,000)$ & $(0,000)$ \\
dsize &,- 00072 &,- 00035 \\
& $(0,001)$ & $(0,001)$ \\
Constant &,- 0027 &,- 015 \\
& $(0,008)$ & $(0,020)$ \\
Observations & 17,476 & 17,476 \\
\hline
\end{tabular}

Standard errors in parentheses

${ }^{* * *} p<0.01,{ }^{* *} p<0.05,{ }^{*} p<0.1$

Tabel 7 memperlihatkan bahwa efek transfer pemerintah melalui Program Raskin tidak memiliki dampak penurunan terhadap jumlah anak usia sekolah yang bekerja. Catatan menarik dari hasil estimasi model dimaksud adalah terdapat bukti statistik yang menunjukkan bahwa gender kepala rumah tangga menentukan banyaknya anak yang bekerja. Kepala rumah tangga laki-laki relatif memiliki pekerja anak usia sekolah yang lebih sedikit. Hasil ini dapat dijadikan rujukan bahwa kepala rumah tangga perempuan cenderung rentan untuk memperkerjakan anak usia sekolah. Jerat kemiskinan dalam hal ini menjadi faktor penting yang menyebabkan masih banyaknya anak usia sekolah yang masih harus bekerja membantu keluarga.

Bukti statistik dari Tabel 4 menunjukkan bahwa Program Raskin dalam taraf tertentu memiliki dampak mendesak (crowding-out) transfer pangan anak terhadap orang tuanya. Meski cakupan transfer yang diteliti hanya meliputi transfer pangan akan tetapi implikasinya akan sangat terasa jika efek ini justru mengurangi net-transfer yang seharusnya diterima keluarga miskin. Penelitian menunjukkan bahwa secara besaran, efek ini tidak terlalu besar (ratarata sekitar Rp60.000,- setahun). Dengan pene- 
litian yang lebih komprehensif, crowding-out effect mungkin akan lebih bisa terdeteksi sebagaimana terjadi baik di negara berkembang maupun negara maju sekalipun.

Beberapa kelemahan dari studi ini mungkin berpotensi mengurangi validitas temuan empiris. Pertama, efek disinsentif bekerja hanya dapat dibuktikan berdasarkan status kerja kepala rumah tangga dan tidak menghitung penurunan alokasi kerja kepala keluarga dalam jam kerja sebagaimana diisyaratkan oleh teori. Bagaimanapun efek penurunan pendapatan dari bekerja turun secara signifikan sehingga efek disinsentif masih dapat dibuktikan secara tidak langsung. Kedua, cakupan transfer lintas rumah tangga relatif terbatas sehingga validitas efek crowding-out seharusnya diinterpretasikan hanya untuk kasus transfer pangan saja (yang dihitung dalam satuan uang). Sementara transfer pendapatan bukan pangan atau yang berupa jasa (non-finansial) bisa jadi merupakan fitur transfer yang lebih dominan disamping transfer finansial dari anak terhadap orang tuanya. Keti$g a$, dari sisi metodologis penelitian ini tidak mengeksplorasi lebih dalam pengaruh heterogenitas level komunitas (desa) yang ditenggarai memiliki pengaruh penting terhadap kinerja Program Raskin. Pendekatan fixed effect hanya sahih jika heterogenitas lintas komunitas adalah tetap antarwaktu sehingga pengaruhnya dapat dieliminir. Jika selama periode penelitian terjadi perubahan karakteristik wilayah yang cukup signifikan, maka perubahan tersebut harus dianalisis secara eksplisit.

\section{SIMPULAN}

Evaluasi dampak program pemerintah seperti Program Raskin sejauh ini hanya meliputi evaluasi terhadap efektivitas pelaksanaan program. Bahwa Program Raskin juga memiliki potensi efek disinsentif bekerja dan mengurangi alokasi bantuan dari sumber lain merupakan hal yang baru dilakukan melalui penelitian dalam paper ini. Hasil penelitian menunjukkan bahwa Program Raskin dalam taraf tertentu berpotensi mengurangi alokasi rumah tangga dalam bekerja. Sebagai akibatnya, pendapatan keluarga dari bekerja menurun signifikan. Selanjutnya, temuan penting juga menunjukkan bahwa terdapat indikasi efek crowding-out Program Raskin terhadap alokasi transfer antargenerasi. Jatah Raskin mengurangi bantuan pangan anak terhadap orang tuanya, meski bukti statistik menunjukkan bahwa temuan ini tidak terlalu kuat. Kontribusi penting dalam penelitian ini adalah melakukan analisis dampak program (public transfer) yang terintegrasi dengan perila$\mathrm{ku}$ transfer antargenerasi (private transfer). Penelitian terdahulu cenderung menganalisis kedua perilaku transfer tersebut secara terpisah.

Isu disinsentif bekerja dan crowding-out effect harus menjadi perhatian pemerintah dalam menjalankan berbagai program agar sasaran yang ingin dicapai bisa dipenuhi secara optimal. Sebagian besar efek negatif dari program pangan yang dilakukan selama ini lebih banyak disebabkan oleh adanya kesalahan target (targetting error). Jika hipotesis ini sahih, maka pemerintah sudah seharusnya melakukan desain ulang terhadap program pengentasan kemiskinan yang akan dilakukan di masa yang akan datang.

Salah satu rekomendasi yang diajukan adalah untuk mendesain program pangan bersyarat (conditional food transfer) untuk mengurangi efek disinsentif bekerja. Pemberian transfer pangan disertai dengan syarat bahwa penerima harus dapat menunjukkan kemajuan prestasi anak (sebagai suatu misal). Dengan demikian, tujuan pengembangan dari suatu program akan tercapai. Di samping itu, program bantuan pangan dirancang sedemikian rupa agar tidak mengurangi kontribusi elemen non-pemerintah (sanak keluarga dan LSM) dalam menjalankan fungsinya sebagai jaring pengaman sosial informal.

Semuanya ini bisa efektif dilakukan jika peran pemerintah lokal yang mengetahui seluk beluk masyarakat sekitarnya diberikan porsi yang lebih besar. Model program terpusat tanpa syarat dan berlaku umum untuk semua daerah harus ditinjau ulang. Meski sangat populis, model kebijakan sentralistik sangat tidak efektif dalam mencapai sasaran perbaikan kesejahteraan masyarakat. 


\section{DAFTAR PUSTAKA}

Abdulai, A., Barret, C., Hoddinott. 2005. Does Food Aid Really Have Disincentive Effect? New Evidence from Sub-Saharan Africa. Word Development, 33, 1689-1704.

Ahmed, V., Sugiyarto, G., \& Jha, S. 2010. Remittances and Household Welfare: A Case Study of Pakistan. ADB Economic Working Paper Series 194.

Barret, C. 2002. Food Aid Effectiveness: It's targeting, stupid. New York: Departement of Applied Economics and Management, Cornell University.

Barret, C., Maxwell. 2005. Food Aid After Fifty Years: Recasting its Role. London: Routledge.

Blundell, R., MaCurdy, T. 2000. Labor Supply: A Review of Alternative Approaches. Dalam D. Ashenfelter, \& D. Card, Hanbook of Labor Economics (hal. 1559-1695). Amsterdam: North-Holland.

Cameron, L., \& Cobb-Clark, D. 2001. Old-Age Support in Developing Countries: Labor Supply, Intergenerational Transfers and Living Arrangements. IZA Discussion Paper No. 289 .

Cox, D. 1990. Intergenerational Transfers and Liquidity Constraints. The Quarterly Journal of Economics, Vol. 105, No. 1, 187-217.

Cox, D., \& Rank, M. R. 1992. Inter-Vivos Transfers and Intergenerational Exchange. The Review of Economics and Statistics, Vol. 74, No. 2, 305-314.

Dercon, S., \& Krishnan, P. 2003. Risk Sharing and Public Transfers. Econoomic Journal, 113, C86-C94.

Frankenberg, E., Lillard, L., \& Willis, R. J. 2002. Patterns of Intergenerational Transfers in Southeast Asia. Journal of Marriage and Family, Vol. 64, No. 3, 627-641.

Gerardi, K., Tsai, Y. 2010. The Effect of Social Entitlement Programs on Private Transfers:
New Evidence of Crowding Out. Atlanta: Federal Reserve Bank of Atlanta.

Gilligan, D. O., Hoddinott. 2007. Is there Persintence in Impavt of Emergency Food Aid? Evidence on Consumption, Food Security and Assets in Rural Ethiopia. American Journal of Agricultural Economics, $89,225-242$.

Jongwanich, J. 2007. Worker's Remittances, Economic Growth and Poverty in Developing Asia and the Pacific Countries. UNESCAP Working Paper.

Kang, S. J. 2004. Are Private Transfer Crowdedout by Public Transfer?: The Case of Nepal. The Developing Economies, XLII-4, 510-528.

Kang, S. J., Suwada, Y. 2003. Are Private Transfers Altruistically Motivated? The Case of Republic of Korea Before and During the Financial Crisis. The Developing Economies, XLI-4, 484-501.

Lafarrere, Anne. 2006. Microeconomic Models of Family Transfer. In: Kolm, Serge-Christophe and Jean Mercier Ythier (Eds.) Handbook of the Economics of Giving, Altruism and Reciprocity, Volume2. Elsevier, 890-969.

Lal, D., Sharma, A. 2009. Private Household Transfers and Poverty Alleviation in Rural India: 1998-99. The Journal of Applied Economic Research , 97-112.

Lentz, E. 2003. Annotated Bibliography of Food Aid Disincentive Effect. New York: Cornell University.

Lillard, L. A., Willis, R. J. 1997. Motives for Intergenerational Transfers: Evidence from Malaysia. Demography, Vol. 34, No. 1, 115135.

Mawardi, S dkk. 2008. Efektivitas Pelaksanaan Raskin. Jakarta: SMERU.

Nguyen, T., Purnamasari, R. 2011. Impacts of International Migration and Remittances on Child Outcomes and Labor Supply in 
Indonesia: How does Gender Matter? Policy Research Working Paper 5591.

Nielsen, M. E., Olinto, P. 2007. Do Conditional Cash Transfers Crowd-out Private Transfers?: Evedence from Randomize Trials in Honduras and Nicaragua. Washington: World Bank .

Park, C. 2003. Interhousehold Transfers between Relatives in Indonesia: Determinants and Motives. Economic Development and Cultural Change, Vol. 51, No. 4, 929945.

Prasetyo, P.E., Marimin dan Samsudin, Adang. 2010. Model Kaji Tindak Program Pembangunan Partisipatif Pengentasan Kemiskinan dan Rawan Pangan. Jurnal Ekonomi Pembangunan, Vol. 11, No.2, 217-235.

Purwaningsih, Yunastiti. dkk. 2010. Pola Pengeluaran Pangan Rumah Tangga Menurut Tingkat Ketahanan Pangan di Provinsi Jawa Tengah. Jurnal Ekonomi Pembangunan, Vol. 11, No.2, 236-253.

Quartey, P. 2006. Migrant Remittances and Household Welfare in Times of Macro-Volatility: The Case of Ghana. ISSER University of Ghana Legon .

Raihan, S., Khondher, H. B., Sugiyarto, G., Jha, S. 2009. Remittances and Household Wel- fare: A Case Study of Bangladesh. $A D B$ Economic Working Paper Series 189.

Raut, L. K., Tran, L.H. 2005. Parental Human Capital Investment and Old-Age Transfers from Children: Is a Loan Contract or Reciprocity for Indonesian Families?. Journal of Development Economics, 77, 389-414.

Sahn, D. E., Alderman, H. 1996. The Effect of Food Subsidies on Labor Supply in Sri Lanka. Economic Development and Cultural Change , 45, 125-145.

Schueler, Dana. 2007. Incentive Effect Transfer within the Extended Family: The Case Indonesia. Disertasi. University of Goettingen.

Skoufias, E., Unar, M., Gonzales, T. 2008. The Impact of Cash and In-kind Transfers on Consumption and Labor Supply. Washington: World Bank.

Sulaiman, M. 2010. Incentive and Crowding-out Effects of Food Assistance: Evidence from Randomized Evaluation of Food-for-Training Project in Southern Sudan. London: Economic Organisation and Public Policy Programme.

Tadesse, G., Shively, G. 2009. Food Aid, Food Prices and Producer Disincentive in Ethiopia. American Journal of Agricultural Economics, 91, 942-955. 